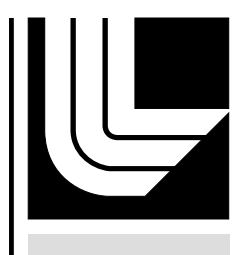

LAW RENCE LIVERMORE N A T IO N A L LABORATORY

Radioactive Waste Management Basis

B. Perkins, R. Hollister

March 21, 2008 
This document was prepared as an account of work sponsored by an agency of the United States government. Neither the United States government nor Lawrence Livermore National Security, LLC, nor any of their employees makes any warranty, expressed or implied, or assumes any legal liability or responsibility for the accuracy, completeness, or usefulness of any information, apparatus, product, or process disclosed, or represents that its use would not infringe privately owned rights. Reference herein to any specific commercial product, process, or service by trade name, trademark, manufacturer, or otherwise does not necessarily constitute or imply its endorsement, recommendation, or favoring by the United States government or Lawrence Livermore National Security, LLC. The views and opinions of authors expressed herein do not necessarily state or reflect those of the United States government or Lawrence Livermore National Security, LLC, and shall not be used for advertising or product endorsement purposes.

This work performed under the auspices of the U.S. Department of Energy by Lawrence Livermore National Laboratory under Contract DE-AC52-07NA27344. 


\title{
RADIOACTIVE WASTE MANAGEMENT BASIS
}

\author{
for the: \\ Lawrence Livermore National Laboratory \\ Prepared for: \\ United States Department of Energy \\ National Nuclear Security Administration \\ Livermore Site Office \\ Livermore, California
}

April 2008

Rev. 2 
This work was performed under the auspices of the U.S. Department of Energy by Lawrence Livermore National Laboratory under Contract DE-AC52-07NA27344. 


\title{
RADIOACTIVE WASTE MANAGEMENT BASIS
}

\author{
for the: \\ Lawrence Livermore National Laboratory \\ Prepared for: \\ United States Department of Energy \\ National Nuclear Security Administration \\ Livermore Site Office \\ Livermore, California
}

April 2008

Rev. 2 
DOE Approvals Page

\title{
RADIOACTIVE WASTE MANAGEMENT BASIS
}

\author{
for the: \\ Lawrence Livermore National Laboratory \\ Prepared for: \\ United States Department of Energy \\ National Nuclear Security Administration \\ Livermore Site Office \\ Livermore, California
}

April 2008

Rev. 2

Approved by:

Date:

Ms. Camille Yuan-Soo Hoo:

Livermore Site Office Manager 
LLNL Approvals Page

\title{
RADIOACTIVE WASTE MANAGEMENT BASIS
}

\author{
for the: \\ Lawrence Livermore National Laboratory \\ Prepared for: \\ United States Department of Energy \\ Livermore Site Office \\ Livermore, California
}

April 2008

Rev. 2

Approved by:

Date:

Approved by:

Date:

Stephanie Goodwin:

Technical Advisor - Nuclear Materials Technology Program

Approved by:

Date:

Mark Martinez:

Deputy Principal Associate Director - Weapons and Complex Integration

Table of Contents 
1. INTRODUCTION 1-1

1.1 Purpose $1-1$

1.2 Scope 1-1

1.3 Updates and Revisions

2. RADIOACTIVE WASTE MANAGEMENT BASIS 2-1

2.1 Radioactive Waste Management Basis Requirements 2-1

2.2 LLNL Radioactive Waste Management Basis 2-1

2.3 Radioactive Waste Management Basis Review 2-2

3. RADIOACTIVE WASTE STREAMS 3-1

3.1 Radioactive Waste Stream Descriptions 3-1

3.1.1 Low-Level Radioactive Waste 3-1

3.1.2 TRU Waste 3-1

3.1.3 Mixed Waste 3-1

3.1.4 California Combined Waste 3-1

3.1.5 Classified Waste 3-2

4. RESPONSIBILITIES 4-1

4.1 Department of Energy/National Nuclear Security Administration 4-1

4.2 Generator 4-1

4.3 Radioactive and Hazardous Waste Management Division 4-1

5. GENERAL REQUIREMENTS 5-1

5.1 Conduct of Operations $5-1$

5.2 Quality Assurance 5-1

5.3 Radiation Protection Program 5-1 
5.4 Defense-In-Depth 5-1

5.5 Resource Conservation and Recovery Act Compliance 5-1

5.6 California Hazardous Waste Regulations 5-2

5.7 Toxic Substances Control Act Compliance 5-2

5.8 Emergency Management 5-2

5.9 Environmental Occurrence Reporting $\quad 5-2$

5.10 Environmental Monitoring $\quad 5-2$

5.11 Work Smart Standards $\quad 5-2$

6. WASTE GENERATION 6-1

6.1 Life Cycle Planning 6-1

6.2 Waste with No Identified Path to Disposal 6-1

7. WASTE CHARACTERIZATION AND DESIGNATION 7-1

7.1 Characterization Methods $\quad 7-1$

7.2 Data Quality Objectives

7.3 Waste Disposal Requisition (WDR) 7-1

8. PACKAGING 8-1

8.1 Packaging Procedures $\quad 8-1$

8.2 Waste Information $\quad 8-1$

$\begin{array}{llr}8.3 & \text { Segregation } & 8-1\end{array}$

9. ON-SITE STORAGE 9-1

9.1 Waste Storage Procedures $\quad 9-1$

9.2 Waste Acceptance Requirements for On-Site Storage 9-1

$\begin{array}{lll}9.3 & \text { Storage Timeline } & 9-2\end{array}$

10. TREATMENT 10-1

10.1 Waste Treatment Procedures $10-1$

10.2 Waste Acceptance Requirements for On-Site Treatment 10-1 
12. DISPOSAL

12.1 Disposal Facility Waste Acceptance Criteria

13. TRAINING

14. WASTE MINIMIZATION AND POLLUTION PREVENTION 


\section{PREFACE}

This Radioactive Waste Management Basis describes the systematic approach for planning, executing, and evaluating the management of radioactive waste at LLNL. The implementation of this document will ensure that waste management activities at LLNL are conducted in compliance with the requirements of DOE Order 435.1, Radioactive Waste Management, and the Implementation Guide for DOE Manual 435.1-1, Radioactive Waste Management Manual. 


\section{ACRONYMS}

CERCLA Comprehensive Environmental Response, Compensation, and Liability Act

CFR Code of Federal Regulations

CHEW Chemical Exchange Warehouse

CWAA Consolidation Waste Accumulation Area

DOE Department of Energy

DQO Data Quality Objectives

EA Environmental Analyst

EPA Environmental Protection Agency

EMS Environmental Management System

ES\&H Environmental Safety and Health

FSP Facility Safety Plan

IGD Information Gathering Document

ISM Integrated Safety Management

IWS Integration Work Sheet

LLNL Lawrence Livermore National Laboratory

LLW Low-Level Waste

LSO Livermore Site Office

MLLW Mixed Low-Level Waste

NCAR Nonconformance and Corrective Action Report

NEPA National Environmental Policy Act

NORM Naturally Occurring Radioactive Material

RCRA Resource Conservation and Recovery Act

RHWM Radioactive and Hazardous Waste Management

RHWM WAC Radioactive and Hazardous Waste Management Waste Acceptance Criteria

RPP Radiological Protection Program

RWMB Radioactive Waste Management Basis

SAA Satellite Accumulation Area

TRU Transuranic Waste

TSCA Toxic Substances Control Act 
Radioactive Waste Management Basis

Preface

Lawrence Livermore National Laboratory

Rev. 2 April 2008

Page ix of xiii

WAA Waste Accumulation Area

WAC Waste Acceptance Criteria

WCP Waste Certification Program

WDR Waste Disposal Requisition

WGS Waste Generator Services

WIPP Waste Isolation Pilot Plant

WSS Work Smart Standards 
by-product material

defense-in-depth

disposal

hazard

high-level waste

life cycle

low-level waste

mixed low-level radioactive waste (mixed waste)

\section{DEFINITIONS}

(1) Any radioactive material (except special nuclear material) yielded in or made radioactive by exposure to the radiation incident to the process of producing or utilizing special nuclear material, and (2) the tailings or wastes produced by the extraction or concentration of uranium or thorium from any ore processed primarily for its source material content. [Source: Atomic Energy Act of 1954, as amended, section 11(e)]

The practice of using physical and administrative systems in a structure of mutual reinforcement to avoid exposure of the public, the workforce, and the environment to nuclear radiation and radioactive materials. [Source: DNFSB/TECH-6]

Emplacement of waste in a manner that ensures protection of the public, workers, and the environment with no intent of retrieval and that requires deliberate action to regain access to the waste. [Source: DOE Order 435.1]

A source of danger (i.e., material, energy source, or operation) with the potential to cause illness, injury, or death to personnel or damage to an operation or to the environment (without regard for the likelihood or credibility of accident scenarios or consequence mitigation). [Source: DOE Manual 411.1-1]

High-level waste is the highly radioactive waste material resulting from the reprocessing of spent nuclear fuel, including liquid waste produced directly in reprocessing and any solid material derived from such liquid waste that contains fission products in sufficient concentrations, and other highly radioactive material that is determined, consistent with existing law, to require permanent isolation. [Adapted from: Nuclear Waste Policy Act of 1982, as amended]

The life of a waste from generator planning through generation, storage, treatment, and disposal. [Adapted from: DOE Order 430.1A]

Low-level radioactive waste is radioactive waste that is not high-level radioactive waste, spent nuclear fuel, transuranic waste, by-product material (as defined in section 11e.(2) of the Atomic Energy Act of 1954, as amended), or naturally occurring radioactive material. [Adapted from: Nuclear Waste Policy Act of 1982, as amended]

Waste that contains both source, special nuclear, or by-product material subject to the Atomic Energy Act of 1954, as amended, and a hazardous component subject to the Resource Conservation and Recovery Act. [Adapted from: Federal Facility Compliance Act of 1992] 
naturally occurring radioactive material (NORM)

non-routine waste

oversight

radioactive waste

radioactive waste management facility/operations/activities

record

release

release of waste
Naturally occurring materials not regulated under the Atomic Energy Act of 1954, as amended, whose composition, radionuclide concentrations, availability, or proximity to man have been increased by or as a result of human practices. NORM does not include the natural radioactivity of rocks or soils, or background radiation. [Adapted from: January 1997 Draft Part N, Regulation and Licensing of Naturally Occurring Radioactive Material, Conference of Radiation Control Program Directors, Inc.]

Waste generated as a result of environmental restoration of contaminated media (soil, groundwater, surface water, sediments, etc.); stabilization of nuclear and non-nuclear (chemical) materials; and deactivation and decommissioning (including decontamination) of facilities. Non-routine waste consists of one-time operations waste produced by environmental restoration program activities, including primary and secondary wastes associated with retrieval and remediation operations; "legacy wastes;" and wastes from decontamination and decommissioning/transition operations. Routine wastes that are disposed of using contracts where the price is negotiated on a case-bycase basis shall be treated as a non-routine waste.

[Adapted from - Albuquerque Operations Office National Pollution Prevention Program June 2002 report to EM-22]

The responsibility and authority assigned to line management to assess the adequacy of DOE and contractor performance. Independent Oversight refers to the responsibility and authority assigned to the Assistant Secretary for Environment, Safety and Health to independently assess the adequacy of DOE and contractor performance. [Adapted from: DOE Manual 411.1-1]

Any garbage, refuse, sludges, and other discarded material, including solid, liquid, semisolid, or contained gaseous material that must be managed for its radioactive content. [Adapted from: 40 CFR Part 240]

All land, structures, other appurtenances, and improvements on the land which generate, treat, store, or dispose of radioactive waste, and the operations and activities associated therewith. [Source: DOE Order 435.1]

A completed document or other medium that provides objective evidence of an item, service, or process. [Source: 10 CFR 830.3]

Any discharging, dumping, emitting, emptying, escaping, injecting, leaching, leaking, pouring, pumping, spilling of radioactive substances into the environment including abandoning any type of receptacle containing radioactive substances, but does not include disposal in a permitted disposal facility. [Adapted from: DOE Glossary]

The exercising of DOE' $s$ authority to release property that has been declared waste from its control after confirming that residual radioactive material on the waste has been determined to meet the guidelines for residual radioactive material in accordance with DOE Order 5400.5, Radiation Protection of the Public and the Environment, and other applicable radiological requirements. [Adapted from: DOE Order 5400.5] 
routine waste

site

source material

special nuclear material

spent nuclear fuel

staging

storage
Normal operations waste produced by any type of production, analytical, and/or research and development laboratory operations; treatment, storage, or disposal operations; "work-for-others;" or any other periodic and recurring work that is considered ongoing. The term "normal operations" refers to the type of ongoing process (e.g., production) not to the specific activity that produced the waste. Periodic laboratory or facility cleanouts and spill cleanups which occur as a result of these processes are also considered normal operations. Routine wastes that are disposed of using contracts where the price is negotiated on a case-by-case basis shall be treated as a non-routine waste. [Adapted from - Albuquerque Operations Office National Pollution Prevention Program June 2002 report to EM-22]

A geographic entity comprising leased or owned land, buildings, and other structures required to perform program activities. [Source: DOE Order 430.1A]

(1) Uranium or thorium, or any combination thereof, in any physical or chemical form or (2) ores which contain by weight one-twentieth of one percent $(0.05 \%)$ or more of (i) uranium, (ii) thorium or (iii) any combination thereof. Source material does not include special nuclear material. [Source: 10 CFR Part 40]

(1) Plutonium, uranium enriched in the isotope 233 or in the isotope 235 , and any other material which is determined, pursuant to the provisions of section 51 [of the Atomic Energy Act of 1954, as amended], to be special nuclear material, but does not include source material; or (2) any material artificially enriched by any of the foregoing, but does not include source material. [Source: Atomic Energy Act of 1954, as amended]

Fuel that has been withdrawn from a nuclear reactor following irradiation, the constituent elements of which have not been separated by reprocessing. Test specimens of fissionable material irradiated for research and development only, and not production of power or plutonium, may be classified as waste, and managed in accordance with the requirements of this Order [435.1] when it is technically infeasible, cost prohibitive, or would increase worker exposure to separate the remaining test specimens from other contaminated material. [Source: DOE Order 435.1]

Storing waste for the purpose of accumulation to facilitate transportation transfer, treatment and/or disposal. [Adapted from: Surplus Plutonium Disposition Draft Environmental Impact Statement, July 1998]

The holding of radioactive waste for a temporary period, at the end of which the waste is treated, disposed of, or stored elsewhere. [Adapted from: $40 \mathrm{CFR}$ Part 260] 
transuranic waste

treatment

waste acceptance criteria (WAC)

waste acceptance requirements

waste certification

waste characterization

waste container

waste designation

waste management

waste stream
Transuranic waste is radioactive waste containing more than 100 nanocuries (3,700 becquerels) of alpha-emitting transuranic isotopes per gram of waste, with half-lives greater than 20 years, except for: (1) high-level radioactive waste; (2) waste that the Secretary of Energy has determined, with the concurrence of the Administrator of the Environmental Protection Agency, does not need the degree of isolation required by the 40 CFR Part 191 disposal regulations; or (3) waste that the Nuclear Regulatory Commission has approved for disposal on a case-by-case basis in accordance with $10 \mathrm{CFR}$ Part 61. [Source: Waste Isolation Pilot Plant (WIPP) Land Withdrawal Act of 1992, as amended]

Any method, technique, or process designed to change the physical or chemical character of waste to render it: less hazardous; safer to transport, store, or dispose of; or reduce its volume. [Source: DOE Order 435.1]

Waste acceptance criteria are the technical and administrative requirements that a waste must meet in order for it to be accepted at a storage, treatment, or disposal facility. [Source: DOE Order 435.1]

Waste acceptance requirements are waste acceptance criteria, and all other requirements that a facility receiving radioactive waste for storage, treatment, or disposal must meet to receive waste (e.g., waste acceptance program requirements, receiving facility operations manual). [Source: DOE Order 435.1]

A process by which a waste generator (LLNL) affirms that a given waste or waste stream meets the waste acceptance criteria of the facility to which the generator intends to transfer waste for treatment, storage, or disposal. [Source: DOE Order 435.1]

The identification of waste composition and properties, by review of acceptable knowledge (which includes process knowledge), or by nondestructive examination, nondestructive assay, or sampling and analysis, to comply with applicable storage, treatment, handling, transportation, and disposal requirements. [Adapted from: DOE Glossary ("Characterization" definition) and Federal Register, Vol. 62, No. 224]

A receptacle for waste, including any liner, shielding, or material that is intended to accompany the waste in disposal. [Source from: DOE Order 435.1]

A determination of the category to which the waste belongs: hazardous, lowlevel radioactive, mixed low-level, etc.

The planning, coordination, and direction of those functions related to generation, handling, treatment, storage, transportation, and disposal of waste, as well as associated surveillance and maintenance activities. [Source: DOE Order 435.1]

A waste or group of wastes from a process or a facility with similar physical, chemical, or radiological properties. [Source: DOE Order 435.1] 


\section{INTRODUCTION}

This Radioactive Waste Management Basis (RWMB) documents radioactive waste management practices adopted at Lawrence Livermore National Laboratory (LLNL) pursuant to Department of Energy (DOE) Order 435.1, Radioactive Waste Management.

\subsection{Purpose}

The purpose of this Radioactive Waste Management Basis is to describe the systematic approach for planning, executing, and evaluating the management of radioactive waste at LLNL. The implementation of this document will ensure that waste management activities at LLNL are conducted in compliance with the requirements of DOE Order 435.1, Radioactive Waste Management, and the Implementation Guide for DOE Manual 435.1-1, Radioactive Waste Management Manual. Technical justification is provided where methods for meeting the requirements of DOE Order 435.1 deviate from the DOE Manual 435.1-1 and Implementation Guide.

\section{$1.2 \quad$ Scope}

The activities covered by this RWMB include the generation, on-site management, characterization, profiling, packaging, storage, transfer, certification, treatment, and off-site disposal of all radioactive wastes, which consist of low-level, transuranic (including mixed transuranic), and mixed low-level radioactive waste (LLW, TRU, and MLLW, respectively). High-level waste is not managed at LLNL and is therefore not included in this plan. Hazardous wastes are covered by other LLNL documents. Non-radioactive wastes are not discussed as part of this RWMB.

\subsection{Updates and Revisions}

This RWMB will be updated as necessary to reflect changes in the regulations, DOE Orders, and significant changes in programs and expected waste streams. At a minimum, the RWMB will be reviewed and revised every three (3) years to ensure that it is current with LLNL's waste management programs and practices. Minor deviations in waste management activities will be addressed in other appropriate documentation. 


\section{RADIOACTIVE WASTE MANAGEMENT BASIS}

DOE adopted the concept of a radioactive waste management basis to provide assurances that controls are developed, documented, and properly implemented for management of radioactive waste. The term "controls" refers to processes, procedures, equipment, instruments, and other items that are intended to reduce the likelihood of, or the consequences from, a problem that could arise from managing radioactive waste. This document describes LLNL programs aimed at assuring the application of proper controls in all radioactive waste management activities.

\subsection{Radioactive Waste Management Basis Requirements}

In accordance with DOE Order 435.1, a radioactive waste management basis must be developed and maintained for each DOE radioactive waste management facility, operation, and activity, and shall:

- Reference or define the conditions under which the facility may operate based on the radioactive waste management documentation;

- Include the applicable elements identified in the specific waste-type chapters of DOE Manual 435.1;

- Be developed using a graded approach process.

The RWMB for low-level and TRU waste facilities, operations, and activities shall consist of physical and administrative controls to ensure the protection of workers, the public, and the environment. The following specific waste management controls shall be part of the Radioactive Waste Management Basis:

- Generators. The waste certification program.

- Treatment Facilities. The waste acceptance requirements and the waste certification program.

- Storage Facilities. The waste acceptance requirements and the waste certification program.

- Disposal Facilities. The performance assessment, composite analysis, disposal authorization statement, closure plan, waste acceptance requirements, and monitoring plan.

The LLNL Radioactive Waste Management Basis includes only the requirements for generators, treatment, and storage facilities. No waste disposal occurs at LLNL, and therefore the disposal facility requirements are not applicable.

\subsection{LLNL Radioactive Waste Management Basis}

The LLNL Waste Management Basis is comprised of this document and other supporting documents. Supporting documents include but are not limited to:

- $\quad$ LLNL. Environmental Safety \&Health Manual, (ES\&H), UCRL-AM-133867, latest revision. 
- $\quad$ LLNL. Integrated Safety Management System Description, UCRL-AR-132791, latest revision.

- LLNL. Radioactive Waste Program Certification and Quality Assurance Plan, UCRL-MA148488 latest revision.

- $\quad$ LLNL. RHWM Division Quality Assurance Plan, latest revision.

- LLNL. Onsite Hazardous Materials Packaging and Transportation Safety Manual, UCRLMA-108269, latest revision.

- $\quad$ LLNL. Waste Acceptance Criteria (WAC), UCRL-MA-115877, latest revision.

\subsection{Radioactive Waste Management Basis Review}

The RWMB must be reviewed and approved by the DOE Field Element Manager or designee. 


\section{RADIOACTIVE WASTE STREAMS}

Waste managed at LLNL consists of laboratory, operations, research, and development material/waste, and decontamination \& decommissioning of contaminated soil and debris generated during remedial activities. The scope of this basis consists of on-site management, storage, treatment, and off-site disposal of low-level, transuranic (including mixed transuranic), and mixed low-level radioactive waste (LLW, TRU, and MLLW, respectively). High-level waste is not managed at LLNL and is therefore not included in this plan. Hazardous wastes are covered by other LLNL documents.

\subsection{Radioactive Waste Stream Descriptions}

\subsubsection{Low-Level Radioactive Waste}

Low-level radioactive waste is radioactive waste that is not high-level radioactive waste, spent nuclear fuel, transuranic waste, and byproduct material (as defined in section 11e (2) of the Atomic Energy Act of 1954 as amended) or naturally occurring radioactive material (NORM).

\subsubsection{TRU Waste}

Transuranic waste is radioactive waste containing $>100$ nanocuries (3700 Bequerels) of alpha-emitting transuranium radionuclides per gram of waste, with half-lives greater than 20 years, except for: (1) highlevel radioactive waste; (2) waste that the Secretary of Energy has determined, with the concurrence of the Administrator of the Environmental Protection Agency (EPA), does not need the degree of isolation required by the 40 Code of Federal Regulations (CFR) Part 191 disposal regulations; or (3) waste that the Nuclear Regulatory Commission has approved for disposal on a case-by-case basis in accordance with 10 CFR Part 61. This also includes transuranic waste that has a RCRA hazardous component.

\subsubsection{Mixed Waste}

Mixed waste is radioactive waste that contains both a radioactive constituent and a Resource Conservation and Recovery Act (RCRA) hazardous constituent. Waste can become mixed because of: (1) generation as mixed waste during an experiment or procedure; (2) exposure of RCRA hazardous waste to unconfined sources of radioactivity to the point that the waste becomes radioactive; or (3) improper waste segregation.

\subsubsection{California Combined Waste}

Waste that meets the definition of LLW and also contains a state of California regulated hazardous constituent only and is free of RCRA hazardous waste constituents.

\footnotetext{
${ }^{*}$ NORM is managed as Low-Level Radioactive Waste.
} 


\subsubsection{Classified Waste}

Waste with a radioactive component that must be protected due to National Security concerns. Classified material that is no longer needed should be sanitized prior to declaring the material a waste. RHWM does not accept any classified waste for storage and disposal. Small quantities of classified low-level waste can be accepted by the Nevada Test Site (NTS), but must be stored by the generator prior to shipment to NTS. There is no identified disposal path/option for TRU, Mixed, or CA Combined wastes that are also classified. DOE must approve these wastes through the disposal path exception process prior to generating the waste. 


\section{RESPONSIBILITIES}

\subsection{Department of Energy/National Nuclear Security Administration}

Provide guidance on Waste Management practices and review, provide direction on the generation of waste without a path to disposal, and provide guidance for waste with an identified disposal path but without an identified funding source to achieve final disposal.

\subsection{Generator}

- Prior to generating a waste with a radioactive component, contact a RHWM representative so that the life-cycle planning on the proposed waste can be completed.

- Properly store and describe the waste they generate to provide Radioactive and Hazardous Waste Management representatives with sufficient information to safely handle and manage the waste.

- For non-routine waste, ensure adequate funding has been identified for offsite treatment and disposal. If Programmatic funding is not available, DOE Livermore Site Office (LSO) line management must approve generation of the waste. If seeking an exception to generate the waste, the DOE LSO Program line management and DOE LSO Environmental Stewardship must concur with the waste generation. Approval will be from the DOE Field Element Manager or designee.

\subsection{Radioactive and Hazardous Waste Management Division}

- Manage or assist in managing the waste from generation to disposal in an environmentally safe manner protective of the worker and public health.

- Develop site-specific procedures to assist the generator in evaluating their waste. The procedures will document the review of the waste stream and record the conclusions.

- Dispose of programmatic waste generated from routine operations. 


\section{GENERAL REQUIREMENTS}

\subsection{Conduct of Operations}

Conduct of operations is addressed in the LLNL ES\&H Manual Volume I, Document 3.5, Conduct of Operations for LLNL Facilities. Document 3.5 implements requirements in DOE O 5480.19, Conduct of Operations Requirements for DOE Facilities.

\subsection{Quality Assurance}

Operations and activities at LLNL are performed in accordance with the requirements of 10 CFR Part 830 Subpart A, Quality Assurance Requirements, and DOE Order 414.1C, Quality Assurance. General Quality Assurance for the laboratory is addressed in the LLNL ES\&H Manual Volume IV, Part 41, Quality Assurance and Configuration Management. Waste related activities impacting quality are controlled by the RHWM Quality Assurance Plan and the Radioactive Waste Program Certification and Quality Assurance Plan, UCRL-MA-148488.

\subsection{Radiation Protection Program}

Operations and activities at LLNL are conducted in conformance with the Radiological Protection Program (RPP) which complies with the applicable requirements of 10CFR 835, Occupational Radiation Protection, and Volume II, Part 20 of the LLNL ES\&H Manual.

\subsection{Defense-In-Depth}

Defense-in-depth principles advocate the use of multiple levels of engineered and administrative controls to provide protection to the public, workers, and the environment. These principles are incorporated where potential uncertainties or vulnerabilities warrant their use during the review and approval of radioactive waste management activities and documents. Waste management activities are evaluated through the Integrated Safety Management (ISM) process and appropriate levels of engineering or administrative controls are applied to ensure the safety of the workers, the public, and the environment.

\subsection{Resource Conservation and Recovery Act Compliance}

LLNL follows the applicable requirements in RCRA as prescribed by 40 CFR, and California regulations Title 22, for hazardous components of mixed waste. LLW determined to contain a hazardous component subject to RCRA is under the purview of the RCRA regulations. RCRA substantive requirements for storage, inspections, management, and treatment of hazardous waste are complied with at LLNL. 


\subsection{California Hazardous Waste Regulations}

In addition to RCRA, LLNL must comply with California's hazardous waste regulations when handling, hazardous waste in California. If LLW contains constituents considered hazardous in California but not hazardous under RCRA, the waste will be stored as a LLW and may be shipped as LLW if shipped to a disposal site outside of California or Nevada.

\subsection{Toxic Substances Control Act Compliance}

Waste containing regulated toxic components, such as polychlorinated biphenyls, asbestos, or other such materials, must be managed in accordance with requirements of the Toxic Substances Control Act (TSCA), as amended. The definitions and other compliance related requirements of TSCA regulated material/waste is incorporated into the LLNL Environmental Protection Department Radioactive and Hazardous Waste Management Division Waste Acceptance Criteria (RHWM WAC). The requirements for storage are addressed in the facility specific Facility Safety Plans (FSPs).

\subsection{Emergency Management}

Emergency management activities at LLNL are covered by the ES\&H Manual, Volume II, Part 22, Emergencies / Earthquakes / Fire.

\subsection{Environmental Occurrence Reporting}

Occurrence reporting is performed through the occurrence reporting office. General guidelines are addressed in the LLNL ES\&H Manual, Volume I, Document 4.3, LLNL Implementation Procedure for Reporting Occurrences to DOE. Document 4.3 implements DOE O 151.1C, Comprehensive Emergency Management System, DOE O 231.1A, Environment, Safety and Health Reporting, and DOE Manual 231.1-2, Occurrence Reporting and Processing of Operations Information.

\subsection{Environmental Monitoring}

Currently environmental monitoring aspects of all operations and activities at LLNL are addressed in DOE O 451.1B, National Environmental Policy Act Compliance Program. The LLNL ES\&H Manual, Volume I, Document 3.6, Environmental Planning, addresses how the program is implemented.

\subsection{Applicability}

DOE M 435.1 describes the requirements and establishes specific responsibilities for implementing DOE O 435.1. The following sections of DOE M 435.1 are identified as being applicable to LLNL: Chapter I General Requirements and Responsibilities; all sections except the DOE Orders incorporated by reference are applicable only to the extent they were adopted site-wide in the LLNS contract, and Sections 1.2.A through 1.2.F are not applicable. Chapter II High-Level Waste Requirements are not applicable. Chapter III Transuranic Waste Requirements, Sections A through Q, apply with the exceptions of Sections B (3), C, D (4), H (1), H (2), N (4), and $\mathrm{P}$ being not applicable. Chapter IV Low-Level Waste Requirements, Sections A through R apply with the exceptions of Sections C, D (4), G (1)(d) 1-5, M (1)(c), M (3), N (2), N (7), P, Q, and R (3). 


\section{WASTE GENERATION}

\subsection{Life Cycle Planning}

In most cases prior to waste generation, planning is performed to address the entire life cycle for all waste streams. The Radioactive and Hazardous Waste Management Division (RHWM) is notified of potential new waste streams through the following avenues:

- Integration Work Sheet (IWS) Process

- National Environmental Policy Act (NEPA) evaluation

- New design package review

- Monthly Radiological Procurements

- Generator, Environmental Analyst (EA), and/or RHWM technician awareness of proposed new waste stream or change to existing waste stream.

- Generator/RHWM development of a characterization document to document process and disposition pathways for radioactive waste

The technical representatives from RHWM evaluate the potential waste stream to identify characterization, storage, management, treatment, and disposal strategies. The life cycle planning process will be used to evaluate potential waste and to identify any waste that does not have an identified path to disposal or does not have a current disposal option.

\subsection{Waste with No Identified Path to Disposal}

LLNL has developed the following definitions to assist in categorizing and managing waste that has No Path to Disposal and therefore must be reported to DOE as waste that does not have a disposal option.

No Path to Disposal - Planned waste that cannot be made, utilizing existing facilities and equipment, to meet the acceptance criteria of any disposal facility. (Cost for characterization, transportation, treatment, and/or disposal are not factors in the evaluation of acceptability of the waste by the disposal facility.)

No Disposal Option - Wastes that can be made to meet the acceptance requirements of a disposal facility, but are cost-prohibitive for characterization, treatment, transportation, and/or disposal. Disposal of non-routine waste is not funded through RHWM

The RHWM form RCG 0003, Disposal Path/Option Evaluation for Radioactive Waste Types form will be used to evaluate the life cycle planning including the disposal path and options.

LLNL will report to DOE Program Line Management any waste streams having no identified path to disposal. The RHWM form RCG 0002, Radioactive Waste Disposal Exception Form will be used to report the following information concerning the potential waste stream:

- Programmatic need to generate the waste.

- Characteristics and issues preventing the disposal of the waste.

- $\quad$ Plans for the safe storage of the waste until disposal can be achieved. 
- Activities and plans for achieving final disposal of the waste.

In keeping with the spirit and intent of DOE O 435.1, LLNL will also report to DOE LSO Program Line Management non-routine waste streams with no identified funding for disposal (i.e., no disposal option). This will ensure DOE concurs with the generation and storage plans for non-routine waste with no identified funding to dispose of the waste. RHWM is funded to dispose of programmatic waste generated from routine operations. Disposal of waste generated from non-routine operations is not covered under the RHWM normal operating budget and must be covered by the program generating the waste or by special funding received from DOE. If the generating program cannot fund the characterization, treatment, and disposal of non-routine waste, DOE line management must approve the generation and storage of that waste. Long-term storage of radioactive waste could lead to the generation of new "legacy" waste. Non-routine waste with no identified funding for disposal will be reported to DOE Program Line Management using the same set of forms as used to report waste with no-path-todisposal. 


\section{WASTE CHARACTERIZATION AND DESIGNATION}

Waste process knowledge evaluation and characterization is critical in determining the management and disposal requirements for each waste stream generated at LLNL.

\subsection{Characterization Methods}

LLW and MLLW are characterized using direct and/or indirect methods. To the extent discernible, process knowledge is used to initially characterize the waste for proper storage and/or disposal. LLNL uses Waste Certification Program (WCP) and/or RHWM procedures to evaluate the information provided by the generator to ensure safe storage according to the RHWM WAC. If more characterization is needed, LLNL may use the Data Quality Objectives (DQO) process or other appropriate Waste Certification Program procedures to further obtain information about the waste. Process knowledge, RHWM WAC, and the disposal facility WAC dictate the type of analysis performed to characterize the waste further, if needed.

\subsection{Data Quality Objectives}

In most cases, the RHWM WAC for storage and the disposal facility WACs are used to identify characterization parameters and acceptable uncertainty in characterization data.

RHWM procedure WIC 140, Data Quality Objectives Process, describes the DQO process. The DQO process includes planning for both the sampling and analytical portions of the characterization process. The Data Quality Objective process must be developed and initialed prior to the implementation and assessment of sampling and analysis activities. This process may be applied to low-level, mixed low-level, and California Combined waste streams at LLNL to plan proper characterization for off-site disposal facilities.

In the case of waste being characterized for release as a clean material, regulatory drivers such as preliminary remediation goals, risk-based action standards, maximum contaminant levels and radioactive waste release criteria established by the Nuclear Regulatory Commission and DOE are used as the characterization parameters. The process for free and authorized release of material is defined in the LLNL ES\&H Volume II, Document 20.2 LLNL Radiological Safety Program for Radioactive Materials.

\subsection{Waste Disposal Requisition (WDR)}

Waste data is collected and recorded on the WDR. The type of data collected is:

- $\quad$ Physical and compatibility characteristics (including hazardous contents);

- Waste volume;

- Weight of the container and contents;

- Identities and activities of radionuclides;

- Characterization information; 
Radioactive Waste Management Basis

Lawrence Livermore National Laboratory
Waste Characterization and Designation

Rev. 2 April 2008

Page 7-2 of 7-2

- Generating source;

- Any other information required for safe storage of the waste. 


\section{PACKAGING}

All waste generated at LLNL is packaged in a manner that provides containment and protection for the duration of the anticipated storage period until disposal is achieved, or until the waste is removed from the container. If waste has the potential for pressurizing or generating flammable or explosive concentrations of gases within the waste container, then vents or other measures that are needed will be installed according to WCP procedures or an equivalent approved procedure as necessary to safely package the waste. If such waste streams might be generated during future activities, safe packaging methods will be evaluated during the life cycle planning process and safe packaging will be prescribed to the generator.

\subsection{Packaging Procedures}

The LLNL ES\&H Manual, LLNL RHWM WAC, RHWM and WCP procedures are the primary documents used for packaging waste. In addition, the LLNL Onsite Hazardous Material Packaging and Transportation Safety Manual can be used as a reference for packaging waste. Containers shall be marked such that their contents can be identified. Waste is packaged in a manner that provides containment and protection for the duration of the anticipated storage period and until disposal is achieved or until the waste is removed from the container or repackaged.

\subsection{Waste Information}

To document the contents, properties, proper packaging, and other relevant characteristics of each waste container, a WDR serves as the record for retention of the minimum required information.

\subsection{Segregation}

LLNL segregates waste by packaging the waste in separate containers. Defense waste is separated from non-defense waste. Low level waste is separated from mixed or combined waste. When possible and space permits, containers may be further separated, but in small or high volume storage locations, this is not always an option. 


\section{ON-SITE STORAGE}

In general, waste is stored in a Satellite Accumulation Area (SAA), Waste Accumulation Area (WAA), 693, 169 Consolidation Waste Accumulation Area (CWAA), 361 CWAA, or the 695/696, 612-storage yard.

\subsection{Waste Storage Procedures}

The FSP for each facility documents the procedures and processes for waste storage, which dictate how waste is stored and managed within the storage areas.

\subsection{Waste Acceptance Requirements for On-Site Storage}

Radioactive waste storage requirements at LLNL are intended to ensure the stability of the facility, minimize the need for long-term active maintenance, and eliminate contact of water with waste. The acceptance requirements for on-site storage at LLNL are detailed in facility specific FSPs, RHWM WAC, and RHWM procedures and specify:

- $\quad$ Allowable activities of specific radionuclides;

- $\quad$ Acceptable waste form and/or container requirements that ensure the chemical and physical stability of waste under conditions that might be encountered during transportation, storage, treatment, or disposal;

- $\quad$ Restrictions or prohibitions on waste, materials, or containers that may adversely affect waste handlers or compromise facility or waste container performance;

- That void spaces within the waste and between the waste and its container shall be reduced to the extent practical;

- That no free liquid is present in solid waste;

- The basis, procedures, and levels of authority required for granting exceptions to the waste acceptance requirements and the required documentation for such exceptions, including disposition as approved or not approved.

LLNL manages the following types of waste as indicated:

- $\quad$ LLW or TRU readily capable of detonation, explosive decomposition, or reaction or explosive reaction with water or pyrophoric materials are managed on a case by case basis or in accordance with WCP procedures and/or equivalent approved procedures.

- $\quad$ LLW or TRU capable of generating by radiolysis or biodegradation, quantities of toxic gases, vapors, or fumes harmful to the public, workers, disposal facility personnel or the long-term structural stability of the disposal site are managed using vents and with materials such as lime for biological waste to reduce degradation or other gas formation; 
- LLW or TRU waste in a gaseous form is managed in appropriate containers on a case by case basis.

\subsection{Storage Timeline}

With Livermore Site Office (LSO) concurrence, LLNL did not accept the 12-month storage limit for LLW, as specified in chapter IV of DOE M 435.1Radioactive Waste Management Manual, but instead created a standard establishing a risk-based storage limit based on dose rates. Any radioactive waste that creates a "high radiation area" as defined in 10 CFR 835 (i.e., a deep dose equivalent rate in excess of $0.1 \mathrm{rem}$ in one hour at $30 \mathrm{~cm}$ from the waste container) will be subject to an eighteen month storage limitation. 


\section{TREATMENT}

Treatment of radioactive waste to provide waste forms acceptable for disposal will be conducted in conformance with treatment procedures. Treatment procedures will define requirements for treatment to ensure that all radioactive waste is treated in a manner that protects the public, workers, and the environment and is in accordance with the LLNL ES\&H Manual and the identified waste disposal facility WAC, if applicable.

\subsection{Waste Treatment Procedures}

The FSP for building 695 documents the procedures and processes for waste treatment and the temporary storage of waste pending disposal off site.

\subsection{Waste Acceptance Requirements for On-Site Treatment}

Radioactive waste treatment requirements at LLNL are intended to ensure the stability of the facility. The acceptance requirements for on-site treatment at LLNL are detailed in facility specific FSPs, RHWM WAC, and RHWM procedures and specify:

- $\quad$ Allowable activities of specific radionuclides;

- Acceptable waste form and/or container requirements that ensure the chemical and physical stability of waste under conditions that might be encountered during transportation, storage, treatment, or disposal;

- $\quad$ Restrictions or prohibitions on waste, materials, or containers that may adversely affect waste handlers or compromise facility or waste container performance;

- The basis, procedures, and levels of authority required for granting exceptions to the waste acceptance requirements and the required documentation for such exceptions, including disposition as approved or not approved. 


\section{TRANSPORTATION}

All radioactive waste is packaged and transported in accordance with relevant U.S. Department of Transportation requirements, DOE Order 460.1B, Packaging and Transportation Safety, and DOE Order 460.2A, Departmental Materials Transportation and Packaging Management. To the extent practical, the volume of waste and number of shipments are minimized.

RHWM procedures and the LLNL Onsite Hazardous Material Packaging and Transportation Safety Manual describe the steps required to ensure safe transportation of radioactive waste including:

- $\quad$ Packaging and labeling of trucks and containers;

- Vehicle safety inspection requirements;

- Radiological surveys and documentation;

- Vehicle placarding requirement, as applicable;

- $\quad$ Emergency contacts. 


\section{DISPOSAL}

\subsection{Disposal Facility Waste Acceptance Criteria}

All waste is evaluated using process knowledge and/or characterized to ensure that it complies with the disposal facility's WAC. Before any additional analytical characterization is undertaken for any waste stream, the WAC requirements for the potential disposal facilities are obtained and characterization is performed as needed to support process knowledge to verify that the waste meets the intended disposal site's WAC. LLNL uses RHWM and/or WCP procedures to certify that the waste is sufficiently characterized to meet the disposal site WAC.

\subsection{Exemption for Use of Non-DOE Facilities}

When feasible, radioactive waste should be sent to DOE facilities for disposal. An exemption letter authorizing LLNL to ship certain waste to non-DOE facilities for disposal is drafted, as needed, for each facility that will be used. The exemption letter will specify the time frame that the non-DOE facility is expected to be used for each waste stream. Such facilities must comply with applicable federal, state, and local requirements in order to accept waste from DOE. LLNL will verify that the non-DOE disposal facilities have all necessary permits, licenses, and approvals for the specific waste being shipped. 


\section{TRAINING}

A training and qualification program commensurate with radioactive waste management job duties and responsibilities is implemented for waste management program personnel and generators, as specified by the $R H W M$ Quality Assurance Plan. Additionally, the LLNL ES\&H Manual describes general health and safety training requirements and hazard communication requirements for LLNL employees that may be exposed to hazardous substances, radiological health hazards, or safety hazards. LLNL ES\&H Manual Document 36.1, Hazardous, Radioactive, and Biological Waste Management Requirements, also addresses radioactive waste training requirements. 


\section{WASTE MINIMIZATION AND POLLUTION PREVENTION}

LLNL has adopted the ISO 14001 Environmental Management System and has integrated the EMS process into the existing ISMS. The resultant EMS promotes responsible environmental stewardship practices that:

- $\quad$ Protect the air, water, land, and other natural and cultural resources;

- Complies with applicable environmental regulations in a cost effective manner;

- $\quad$ Focuses on continuous improvement of LLNL environmental performance;

- $\quad$ And uses pollution prevention methods and other sustainable business approaches.

LLNL is committed to minimizing waste volumes by giving preference to source reduction, material substitution, decontamination, and recycling. Applicable waste minimization activities include:

- Avoiding the use of porous materials that cannot be decontaminated;

- Minimizing personal protective equipment waste through effective planning;

- Using real-time analyses to delineate the extent of contamination;

- Optimizing waste container utilization and recycling;

- $\quad$ Removing surface contamination from subsurface structures and pipes;

- Re-using chemical or radioactive material through the Chemical Exchange Warehouse (CHEW);

- Volume reduction through treatment.

A detailed description of the LLNL Waste Minimization Program is located in ES\&H Manual, Volume III, Document 30.1, and Managing Environmental Aspects through Pollution Prevention. 


\section{SHUTDOWN OR CURTAILMENT OF ACTIVITIES}

If conditions are identified that suggest a deviation from the requirements of the waste management or operations procedures, then the activities will be curtailed or facilities shut down until the deficiencies are evaluated and/or corrected and the waste management activities can be carried out in accordance with the approved procedure or guideline. A Nonconformance and Corrective Action Report (NCAR) and follow-up action should be performed in accordance with WCP or RHWM procedures. 